\title{
SM-1 \\ RESEARCH AND DEVELOPMENT PROGRAM \\ INTERIM REPORT NO. 2 \\ ON \\ CORE MEASUREMENTS \\ TASK NO. VII
}




\section{DISCLAIMER}

This report was prepared as an account of work sponsored by an agency of the United States Government. Neither the United States Government nor any agency Thereof, nor any of their employees, makes any warranty, express or implied, or assumes any legal liability or responsibility for the accuracy, completeness, or usefulness of any information, apparatus, product, or process disclosed, or represents that its use would not infringe privately owned rights. Reference herein to any specific commercial product, process, or service by trade name, trademark, manufacturer, or otherwise does not necessarily constitute or imply its endorsement, recommendation, or favoring by the United States Government or any agency thereof. The views and opinions of authors expressed herein do not necessarily state or reflect those of the United States Government or any agency thereof. 


\section{DISCLAIMER}

Portions of this document may be illegible in electronic image products. Images are produced from the best available original document. 
SM-1

RESEARCH AND DEVELOPMENT PROGRAM;

INTERIM REPORT NO. 2

ON

CORE MEASUREMENTS

TASK NO. VII

\section{ARMY PACKAGE POWER REACTOR}

CONTRACT AT $(30-3)-326$

Issued June 30, 1959

S.D. MacKay - Project Engineer
By: S.D. MacKay
D. C. Tubbs

Alco Products, Inc. Post Office Box 414 Schenectady, $\mathrm{N}_{*}$. Y. 


\section{DISTRIBUTION}

COPIES

New York Operations Office

U.S. Atomic Energy Commission

70 Columbus Avenue

New. York :23, New York

ATTENTION: Capt. Richard L. Harris

(V. J. Del.Vecchia for C)

U. S. Atomic Energy Commission

Washington 25 , D. C.

ATTENTION: Classified Technical Library for Co1..D.. G. Williams

U. S Atomic Energy Commission

Army Reactors Branch.

Division of Reactor Development

Washington 25, D. C.

ATTENTION: Major Paul $\mathrm{H}_{0}$. Ugis

U. S. Atomic Energy Commission

Chief, Patents Branch

Washington 25 , D. C.

ATTENTION: Roland A. Anderson

9

U. S. Atomic Energy Commission

Chicago Operations Office

P. O. Box 59

Lemont, Illinois

ATTENTION: Captain J. Schweizer

U. S. Atomic Energy Commission

Idaho Operations Office

Phillips Petroleum Company, NRTS

Technical Library

P.0. Box 1250

Idaho Falls, Idaho

ATTENTION: Major Robert L. Ednie 
COPIES

11

Nuclear Power Field Office

USERDL

Fort Belvoir, Virginia

ATTENTION: Major W. R. Wray

12 Union Carbide Nuclear Corporation

Oak Ridge National Laboratory

Y-12 Building $9704-1$

P. 0. Box "Y"

Oak Ridge, : Tennessee

ATTENTION: A, L. Boch

13 District Engineer, Alaska District

U. S. Army Corps of Engineers.

P. 0. Box 7002

Anchorage, Alaska

ATTENTION: : NPAVG-N

14 The Martin Company

P. 0. Box 5042

Middle River, Maryland

ATTENTION: AEC Contract Document Custodian

$15-40$

Multilith

Master

41

$42-43$
U. S. Atomic Energy Commission

Reference Branch

Technical Information Services Extension

P. . 0. . Box 62

Oak Ridge, Tennessee

Dr. Lawrence $\mathrm{R}_{0}$, Quarles

Dean, School of Engineering

University of Virginia

Charlottesville, Virginia

ATIENTION: Dr. J. L . Meem $\mathrm{J}_{\varphi}$

Alco Products, Inc.

P. O. Box 145

Fort Belvoir, Virginia

ATTENTION: H. L. . Weinberg 


\section{DISTRIBUTION (CONT'D)}

\section{COPIES}

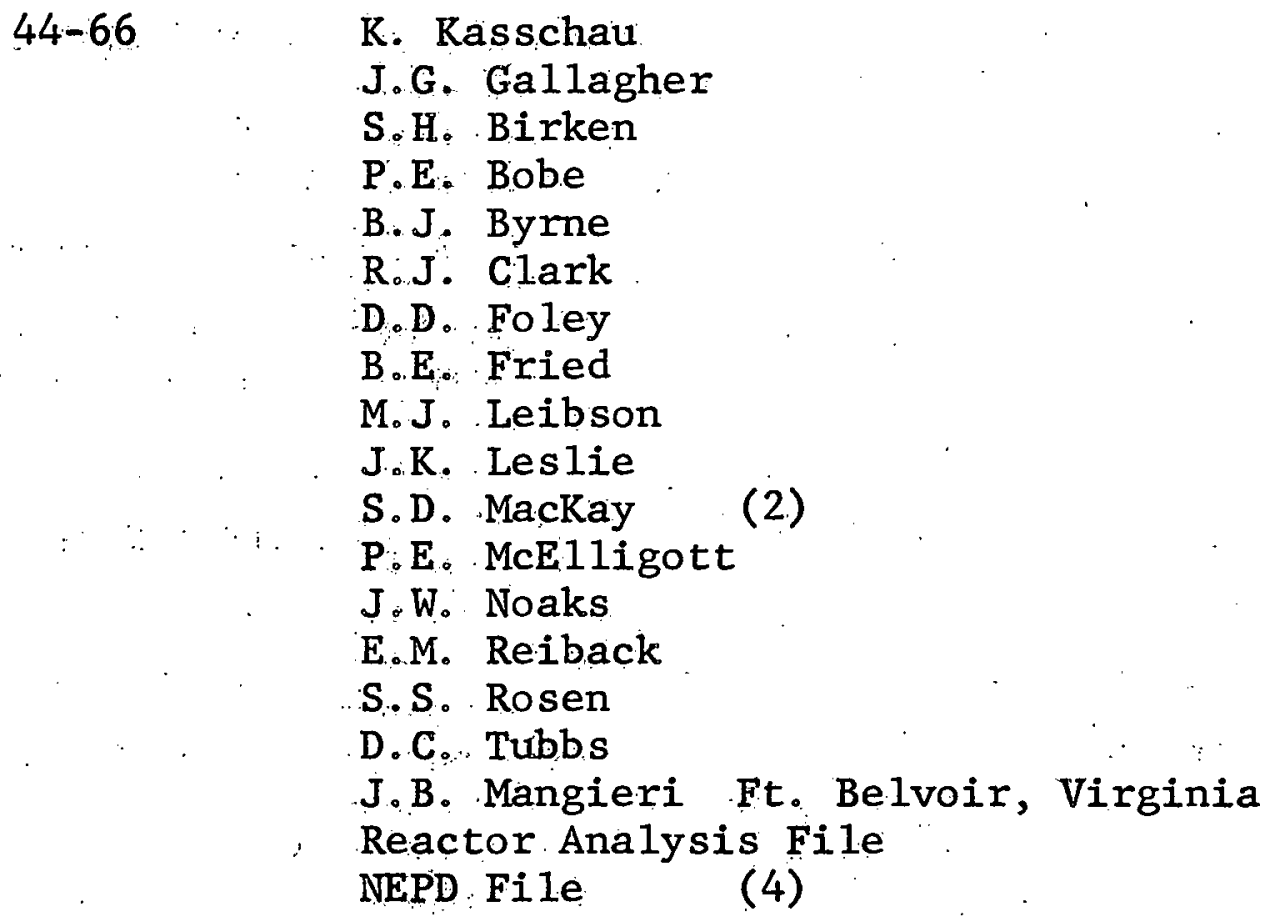




\section{ABSTRACT}

Physics experiments were performed on the : $\mathrm{SM}-1$ core under Research and Development Task No, VII. Measurements were made on five rod bank positions and rod calibrations, The reactiym ity effects of core modifications were investigated . Modificas tions to the core included replacement of the boron absorbers in rods $1,2,3,4$ and $\mathrm{C}$ with europium absorbers; replacement of a control rod fuel element with one containing an integral europium flux suppressor; and replacement of a stationary fue.1 element. Additional experiments were designed to determine the reactivity of the SM-1 with 4 and 8 stationary elements removed; the neutron flux in the biological shield and in the region of an integral europium flux suppressor; and the gamma flux above the core and from irradiated control rod components. 
1.0 INTRODUGTION

Page

2.0 EXPERIMENTAL WORK PERFORMED

2. 1 Five Rod Bank Position

2.2. Rod Calibrations

2.3 Source Multiplication

2. 4 Core Modifications Effects

2.4.1 Temperaturre and Pressure Coefficient

2. 4:2 Five Rod Bank Position

2.4..3 Rod Calibrations

2.4.4 Startup Count Rate

2.4.5 Stuck Rod Conditions

2.5 Reactivity of Smaller Cores

2.6 Neutron Flux Measurements

2.6.1 Shielding

39

2.6.2 . Europium Flux Suppressor

43

2. 7. Gamma Dose Rate Measurements

2.7.1 Above the Core

2.7.2 Control Rod Components 
2.1.1 Five Rod Bank Positions as a Function of Energy Release (several core conditions)

2.1.2 Five Rod Bank Position as a Function of Energy Release (with extrapolation)

2.1.3 Energy Release as a Function of Calendar Time 7

2.2.1 Rod A Calibration 9

2.2.2 Rod A Calibration as a Function of the Five 13

2. 2.3 Reactivity Worth of a Boron-10 Absorber Fully Inserted in Rod C Position

2.3.1 High Voltage Characteristic Curve for Various Times after Shutdown (Nancy Wood).

2.3.2 High Voltage Characteristic Curve for

Various Times after Shutdown (Westinghouse)

2:4.1 Core Array

2.5. 1 Differential Five Rod Bank: Worth 31

2.5.2 Extrapolated Differential Five Rod Bank Worth 35

2.5.3 Reactivity Remaining with Five Rod Bank 37

2.6.1 Neutron F1ux through Primary Shield at $10 \mathrm{MW}$

2.6.2 Therma1 Flux Peaking due to Contro1 Rod Water Gap

2.7.1 Gamma Dose Rate above the Core

2.7.2 Gamma Dose Rate (Safety Rod A Fue1 Element Section) 


\section{LIST OF TABLES}

Table

Title

Page:

2. I-1 Five Rod Bank Calibration

15

2. 4-1 Comparison of Boron and Europium Absorbers

28

2.5-1 Reactivity Changes Associated with Fuel

33 Element Changes

2.7-1 Gamma Dose Rate from Safety Rod A Boron Absorber Element

2. 7-2 Gamma Dose Rate from Safety, Rod A Cap 


\subsection{INTRODUCTION}

This report is the second interim report on $S M-1$ core measurements, covering the period from November, 1958 to June 30 , 1959. The experimental work was performed under Task VII of the SM-1 Research and Development program. . The experiments wil1 provide a basis for evaluating the nuclear performance of the SM-1 Core. The first interim report ${ }^{1}$ (issued March 1, 1959) on core measurements to November 1958, included a description of the SM-1 and the experimental techniques developed for core measurements. A final report on core measurements during the entire lifetime of core I will be issued in early 1960 .

\subsection{EXPERIMENTAL WORK PERFORMED}

From November, 1958 to June 30, 1959 (from 9.1 MWYR to apm proximately 11 MWY of energy release) no shut-downs were scheduled for core measurements. However, the SM-1 was shut down on March 6, 1959, and the pressure vesse1 head was removed to allow physical examination of the core and fuel elements Some core data were obtained while the pressure vesse 1 was open. Work performed under stipulated Task VII experiments included plotting of five rod bank positions; rod calibrations; and source multiplication. Experimental work was also performed to determine the effect of modifications on the core, such as the replacement of a stationary fuel element; the replacement of a control rod fuel element with one containing an integral europium flux suppressor; and the replacement of boron absorbers in control rods $1,2,3,4$, and $C$, with europium absorbers. Other experiments were designed to determine the reactivity of the $S M-1$ core with 4 and 8 furel elements removed; the neutron flux in the region of the integral europium flux suppressor and in the biological shield; and the gamma flux above the core and from irradiated control rod components. 


\subsection{Five Rod Bank Position}

The critical five rod bank positions for several conditions were obtained. The critical bank position at $70^{\circ} \mathrm{F}$, no xenon, 10.5 MWYR burn-up was 7.20 inches. . The critical bank position at $440^{\circ} \mathrm{F}$, equilibrium xenon, 10.7 MWYR burn-up, was 12.86 inches. These positions are shown in Fig. 2.1.1, where the five rod bank position is plotted as a function of energy release. The ritio cal five rod bank position with the boron absorbers in control rods $1,2,3,4$, and $C$, replaced by europium absorbers at $70^{\circ} \mathrm{F}$, no xenon, 10.5 MWYR, was 7.09 inches.

The hot, equilibrium xenon bank position at 10.7 MWYR burn up is approximately 0,3 inches below the fitted extrapolation of bank position plotted as a function of energy release as shown in Fig. 2.1.2. A displacement of -0.2 inches in the hot, equilibrium xenon bank position was expected as a result of the core modifications (see Section $2.4 .2 \mathrm{C}$ ). Since the latest point falls 0.3 inches below the extrapolated curve, this indicates that the fitted extrapolation may under estimate core life..

The energy release plotted as a function of calendar time is shown in Fig. 2.1,3. Assuming a load factor of $62 \%$ shown in Fig. 2.1.3, and 15 MWYR energy release, the end of core life will occur in January, 1960:

\subsection{Rod Calibrations}

Rod calibrations were performed at approximately $70^{\circ}$. with no xenon present. Rod A was calibrated by the period method ${ }_{s}$. and the five rod bank was calibrated from the integral rod $A$ worth.

Three calibrations of rod $A$ at a burnmup of $10_{4} 5$ MWYR with rod $B$ at 19 inches are shown in Fig. 2.2.1. Two of the calibram tions were performed as a function of the position of the five 


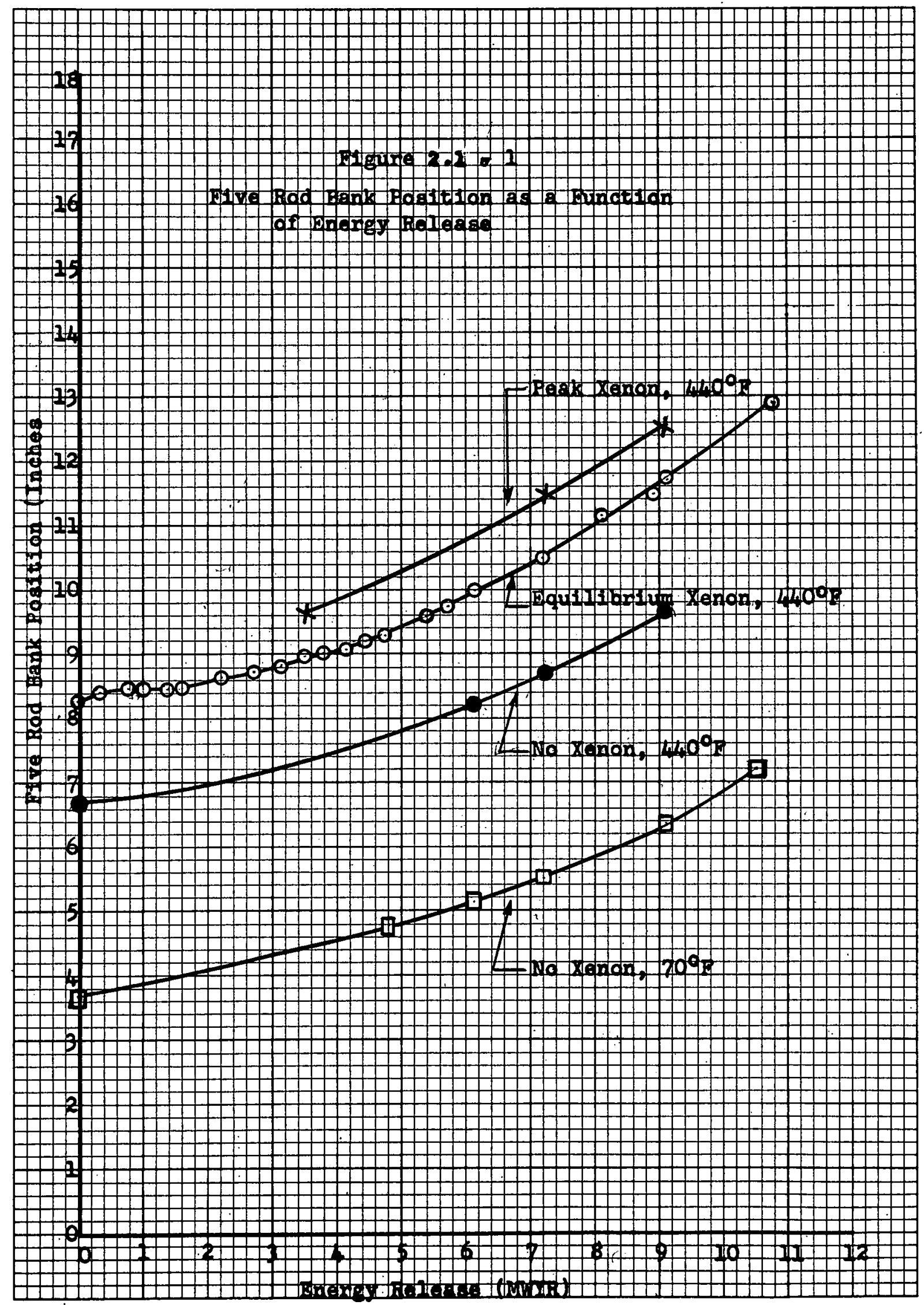









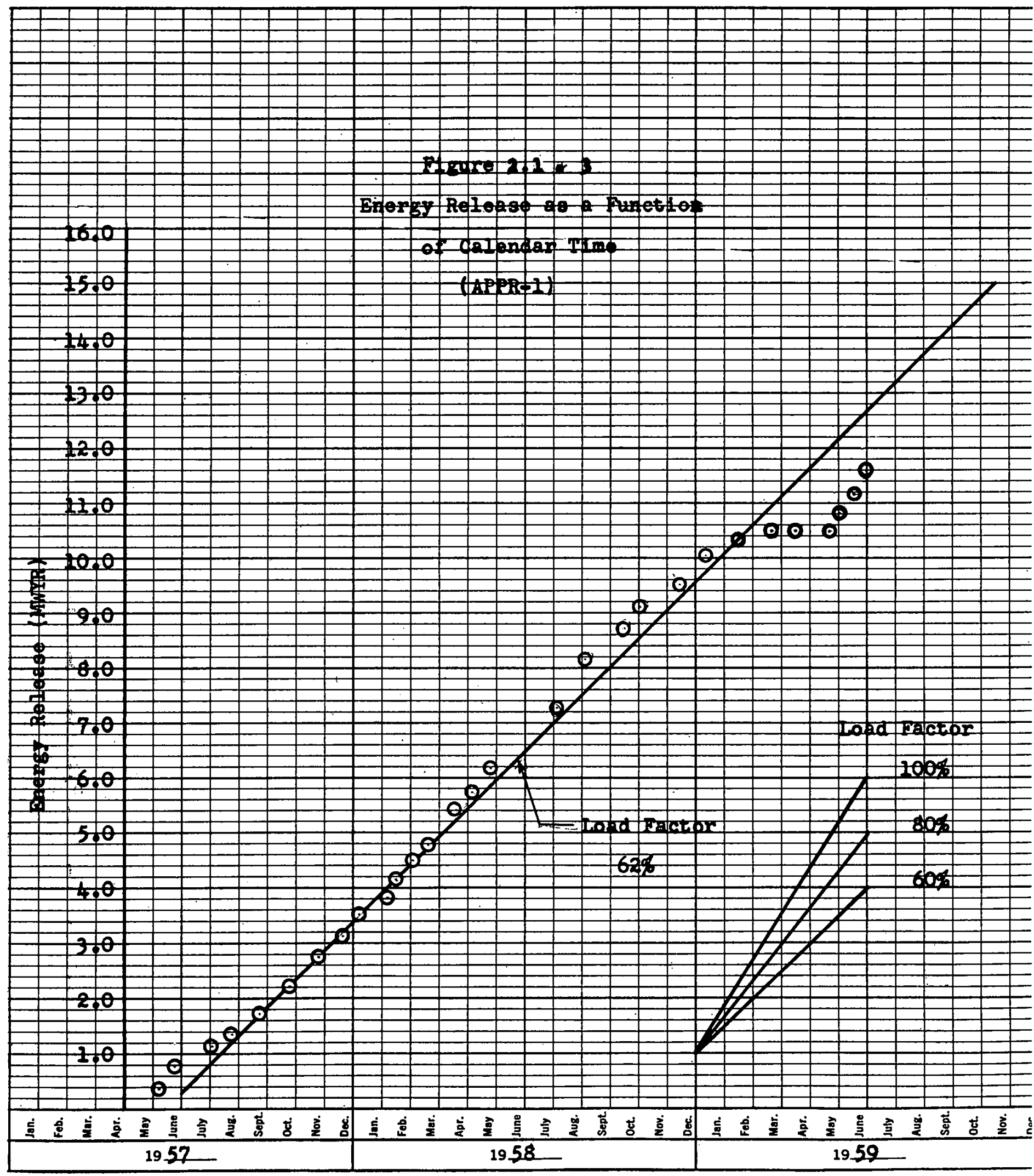




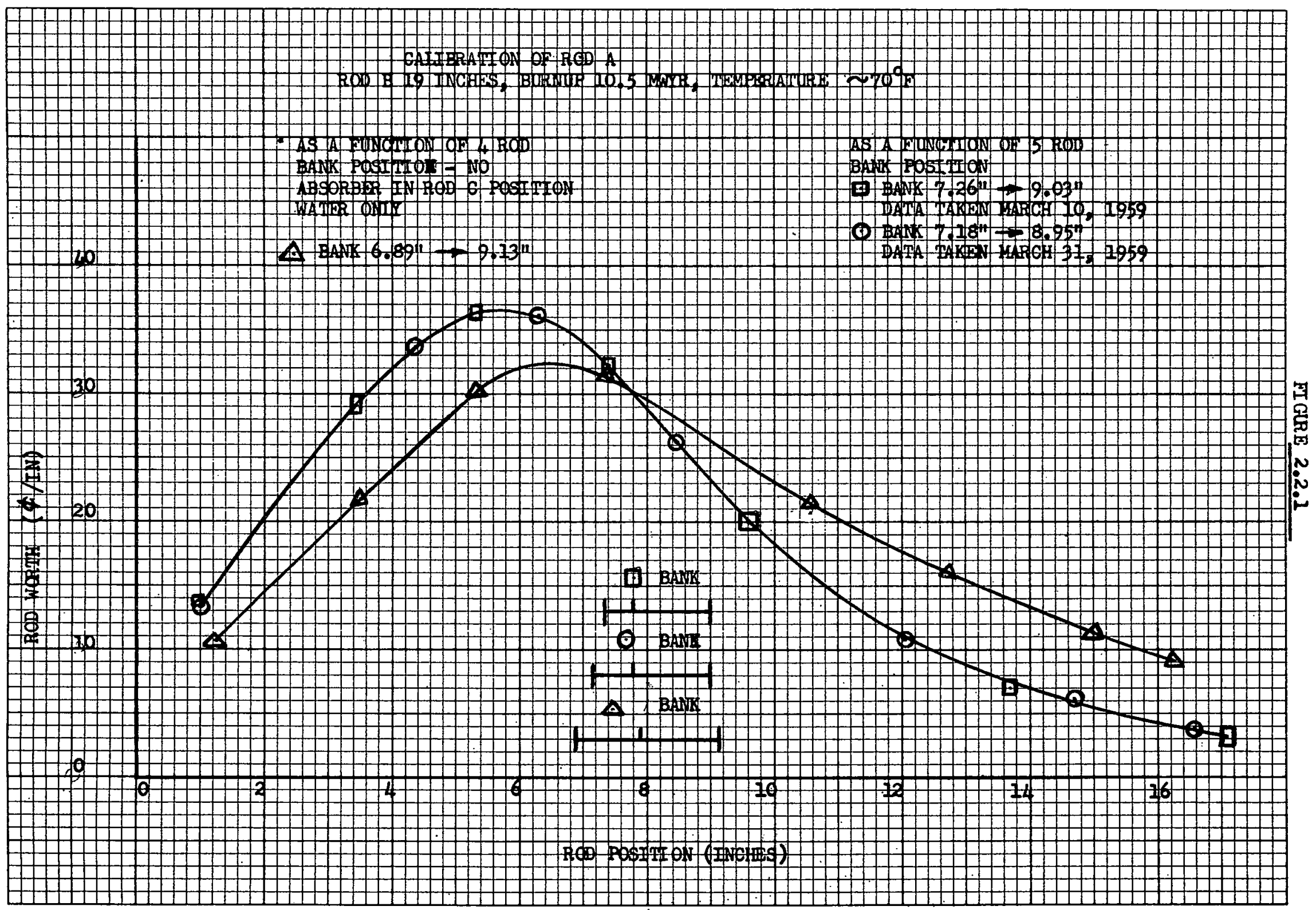


rod bank. The third calibration was performed as a function of the four rod bank position with the absorber and fuel sections removed from rod $C$ position, leaving water in that position. The two curves in the figure have approximately the same integral worth ( $321 \pm 6$ cents). The figure shows that the removal of fuel and absorber from rod $C$ increases the worth of rod $A$ in the abim sorber region of the core (above the bank), but decreases the worth in the a11-fuel region (below the bank).

The calibrations of rod $A$ as a function of the five rod bank position for the normal SM-1 core and the 41 and 37 element: cores are shown in Fig. 2.2.2. The calibrations were performed at a burn-up of 10.5 MWY, with rod B at 19 inches. The bank motion and the position at which rod A is even with the bank is shown for each core configuration. The original boron absorbers in rods $1,2,3,4$, and $C$, were replaced by new europium absorb ers before these calibrations were performed.

The integral worth of rod $\mathrm{A}$ in various cores was obtained by integrating the differential worth curves shown in Fig. $2,2,2$, The integral worth is given for each case in Table 2,2 . ${ }^{\text {rothe }}$ five rod bank position at the terminal points of the integration are also given in the table. The differential bank worth was calculated by dividing the integral worth of rod $A$ by the cor responding motion in the five rod bank as given in Table 2.21 .

The reactivity worths of several boron-10 absorbers fully inserted in the rod C position are shown in Fig . 2.2.3. The worth of a stainless steel absorber was taken as 0 cents, and other absorbers were evaluated relative to the steel absorber.

The reactivity worth is plotted as a function of weight of B-10 in the absorber. Figure $2,2.3$ shows data from a europium absorber plotted so that the number of europium atoms equal the number of boron atoms. 


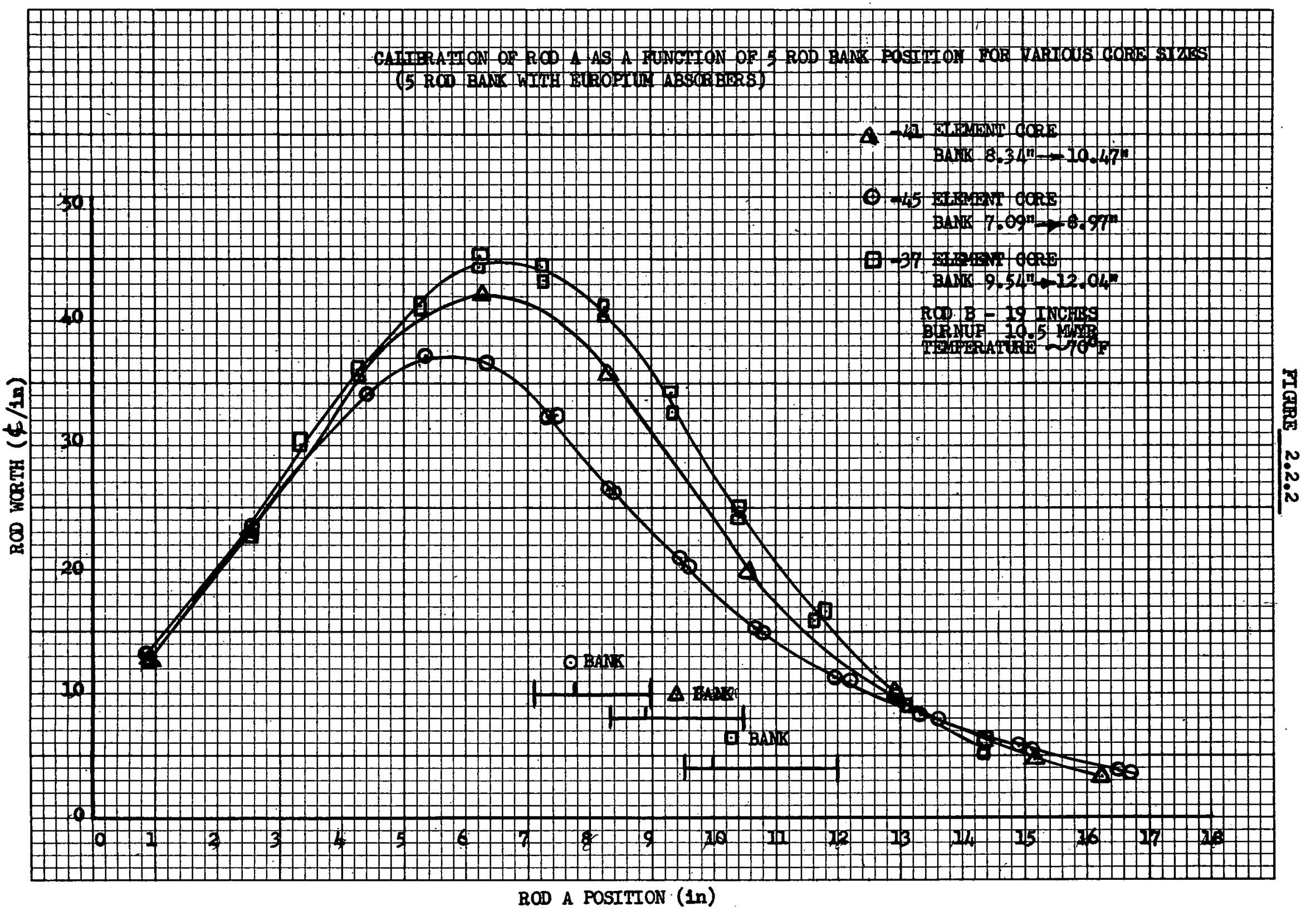


Table $2.2-1$

Five Rod Bank Calibration

\begin{tabular}{|c|c|c|c|c|c|}
\hline $\begin{array}{l}\text { Number of } \\
\text { Elements } \\
\text { in the } \\
\text { Core }\end{array}$ & $\begin{array}{l}\text { Rod A } \\
\text { Position } \\
\text { (inches }\end{array}$ & $\begin{array}{l}\text { Integrated } \\
\text { Rod. A. Worth } \\
\text { (cents) }\end{array}$ & $\begin{array}{l}\text { Five Rod Bank } \\
\text { Position } \\
\text { (inches) }\end{array}$ & $\begin{array}{l}\text { Average } \\
\text { Bank Position } \\
\text { (inches) }\end{array}$ & $\begin{array}{l}\text { Average } \\
\text { Bank Worth } \\
\text { (cents/inçh) }\end{array}$ \\
\hline \multirow{3}{*}{45} & 0.00 & & 8.97 & \multirow{3}{*}{8.03} & \multirow{3}{*}{175.8} \\
\hline & & 330.5 & & & \\
\hline & 18.00 & & 7.09 & & \\
\hline \multirow{3}{*}{41} & 1.00 & & 10.47 & \multirow{3}{*}{9.41} & \multirow{3}{*}{167.6} \\
\hline & & 356.9 & & & \\
\hline & 16.00 & & 8.34 & & \\
\hline \multirow{3}{*}{37} & 0.00 & & 12.04 & \multirow{3}{*}{$10: 79$} & \multirow{3}{*}{158,4} \\
\hline & & 395.9 & & & \\
\hline & 18.00 & 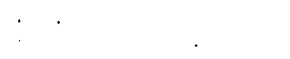 & 9.54 & & \\
\hline
\end{tabular}


FIGURE 2.2 .3

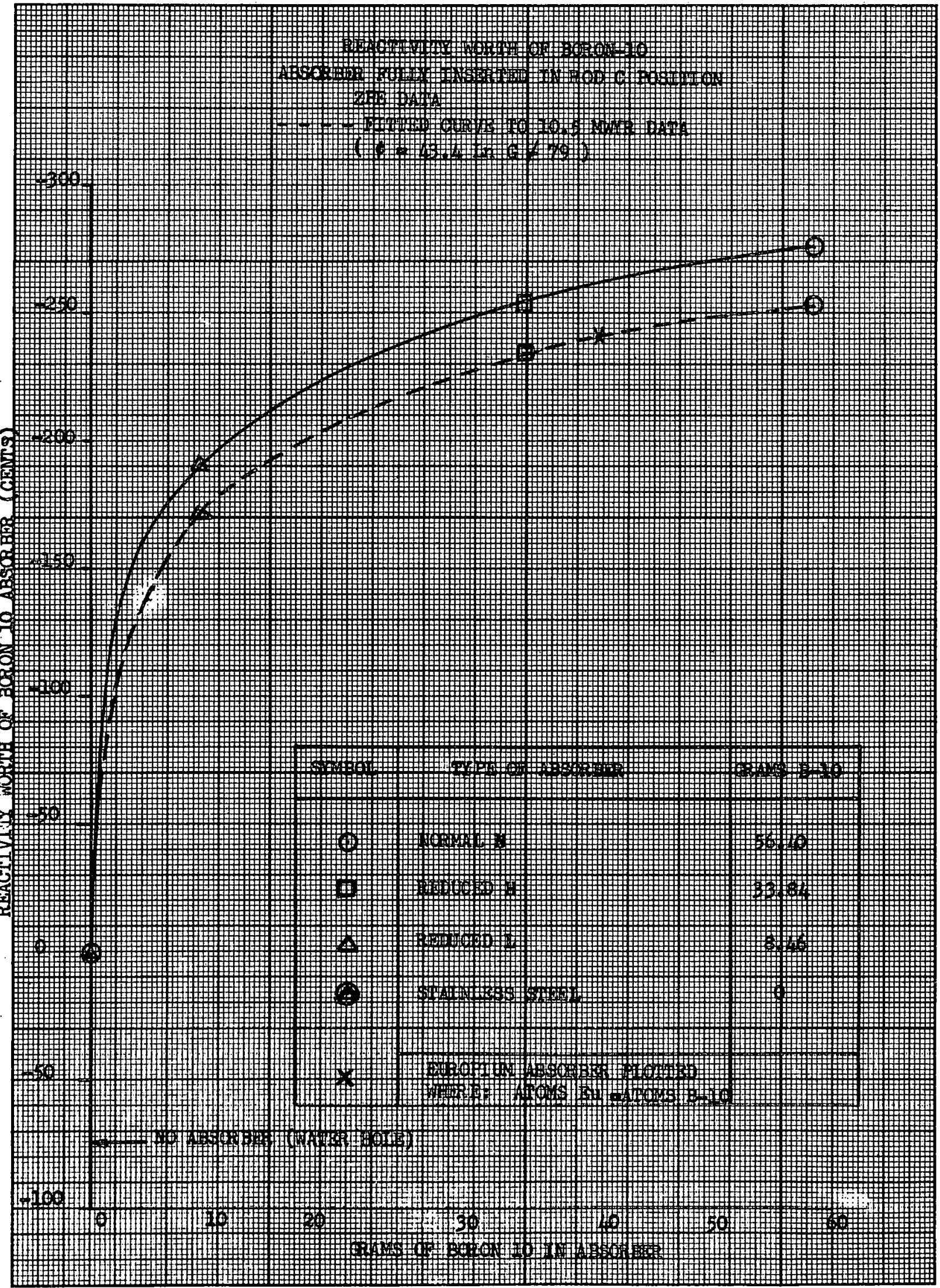




\section{3 : Source Multiplication}

Data was recorded from two $\mathrm{BF}_{3}$ neutron counters for various times after shut-down from full power. Relative count rate plotted as a function of counter high voltage is shown for the two counters in Figures 2.3 .1 and 2.3.2. The counter performance is unsatisfactory for short times after shut-down, but the performance improves with increasing time after shut-down. The high gamma flux shortly after shut-down apparently is responsible for the poor performance; however, activations in the counter walls could also contribute to the loss of plateau. The gamma dose rate for various times after shut-down as given in Figures 2.3.1 and 2.3.2 was obtained from shielding measurements ${ }^{3}$.

2.4 Core Modifications

On May 8,1959 , the following modifications were completed. on the SM-1 core:

1. The boron absorbers in control rods $1,2,3,4$, and 6 . were replaced by europium absorbers numbered $1,5,4,9$ 6 , and 8 , respectively.

2. The fuel element in control rod 4 was replaced by a new control rod fuel element containing an integral europium flux suppressor:

3. The stationary fuel element from position 56 was rotated $180^{\circ}$ and used to replace the element removed from posi tion 57 .

4. A spare, unused core I stationary fuel element was placed in position 56 .

The position numbers in the core are shown in Fig. $2,4,1$, The hazards associated with the modifications were evaluated and are reported in APAE Memo $194^{4}$. The effects on core measurements are described below. 
FIGURE 2.3.1

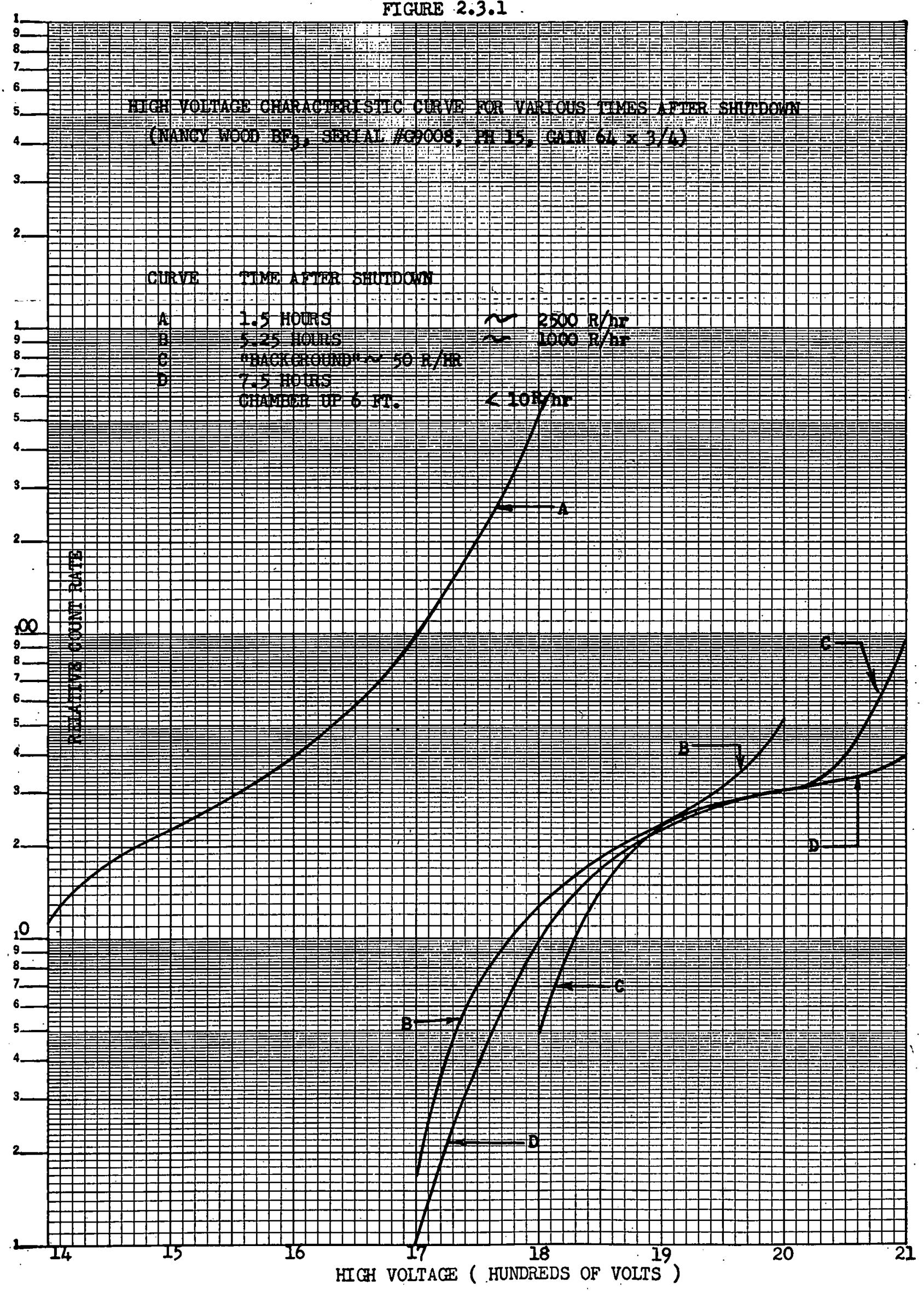


FIGURE 2.3 .2

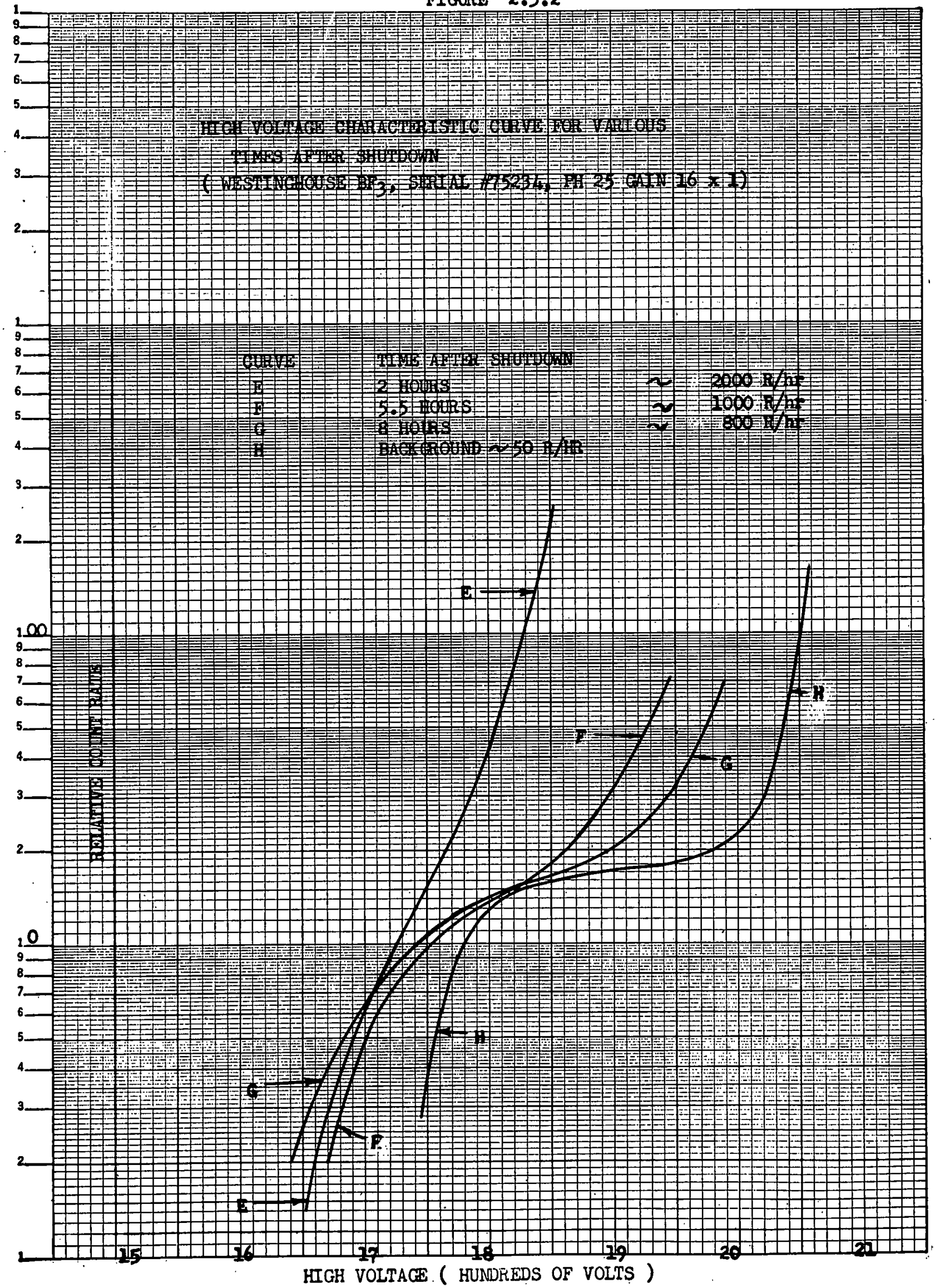


FIG. 2. 4.1

CORE ARRAY

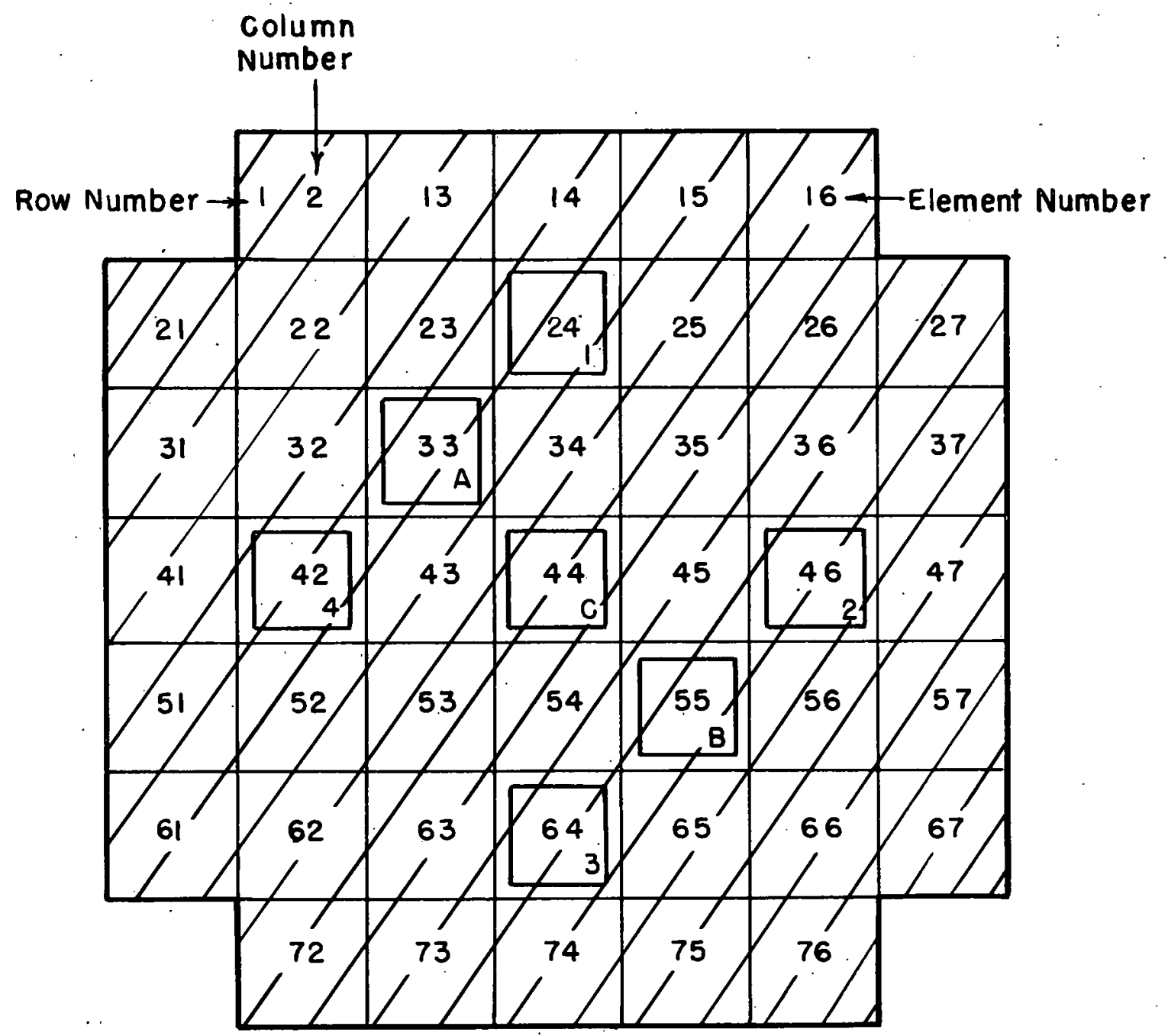




\subsubsection{Temperature and Pressurre Coefficient}

Since the temperature and pressure coefficients are primarily functions of the water volume fraction small changes in fuel and absorber loading will have a negligible effect on this experiment

\section{2.:4:2 Bank Positions}

A. Replacement of Boron Absorbers with Europium Absorbers

The cold no xenon 5 rod bank position was 7.020 inches with original boron absorbers and 7 . 09 inches with new europium absorbers. The reactivity associated with the replacement was evaluated by several methods and is $20 . \pm 5 \%$ This should wause a displacement of approximately -0.1 inches in the operating bank position at approximately 12.8 inches (10.5 MWYR) . The correction can be made in the plot of bank position as a function of energy release, and the correction will diminish to zexo at the :end of core life.

A new boron absorber was used as a reference for comparisom with europium absorber worth as given in Table 2.4 1. The meastrement was performed by fully inserting the absorber, new boron or europium; in rod $C$ position and determining the critical four rod bank position . Differences in the four rod bank position were converted to reactivity changes using a measured worth of 143 cents per inch for the four rod bank from 8.7 to 9.1 inches.

\section{B. Replacement of Fúl Elements}

The net reactivity effect of moving and rotating the fuei element from position 56 to position 57 and the replacement of fuel elements in rod 4 and position 56 was estimated as $0 \times 084 \%$ \% or 11.5 cents. This would cause a displacement of 0.1 inches in the operating bank position at $10.5 \mathrm{MW} \mathrm{R}_{\text {. }}$. The increase in core life due to the addition of the se fuel elements is estimated at 0.2 to 0.5 MWY R. 
COMPARISON OF BORON AND EUROPIUM ABSORBERS

\begin{tabular}{|c|c|c|c|c|}
\hline \multicolumn{2}{|c|}{ ABSORBER } & $\begin{array}{l}\text { FOUR ROD BANK } \\
\text { POSITION } \\
\text { (INCHES) }\end{array}$ & $\begin{array}{l}\text { CHANGE IN BANK } \\
\text { POSITION } \\
\text { (INCHES) }\end{array}$ & $\begin{array}{c}\text { DIFFERENCE IN WORTH } \\
\text { (CENTS) }\end{array}$ \\
\hline \multicolumn{2}{|c|}{$\begin{array}{c}\text { Boron } \begin{array}{c}\# 16 \text { (New } \\
\text { (reference) }\end{array}\end{array}$} & 9.039 & 0 & 0 \\
\hline \multirow{6}{*}{ 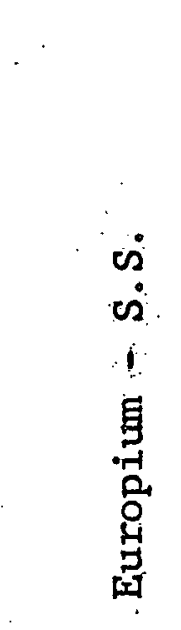 } & 非 & 8.944 & -0.095 & +13.6 \\
\hline & \#4 & 8.944 & -0.095 & +13.6 \\
\hline & 非 & $8: 942$ & -0.097 & +13.9 \\
\hline & 非 6 & .8 .942 & -0.097 & +13.9 \\
\hline & 非 8 & 8.947 & -0.092 & +13.2 \\
\hline & 非3 & 8.768 & -0.271 & +38.8 \\
\hline$\therefore$ & 非 7 . & 8.772 & -0.267 & +38.2 \\
\hline \multicolumn{2}{|c|}{ Boron (Used 10.5 MWYR) } & & & +1.9 \\
\hline
\end{tabular}

* Positive sign indicates less poisonous rod. 


\section{Net Effect on Bank Positions}

The net effect of absorber replacement and fuel element changes on the operating bank position will be to displace the bank approximate $1 y$ - 0.2 inches at 10,5 MWY

\subsubsection{Rod Calibrations}

The effect of eore modifications on rod calibrations will be negligible.

\section{2:.4.4 Start-15p Count Rate}

The core modifications will have negligible effect on start tip count rate.

\subsubsection{Stuck Rod Conditions}

The change in safety margin as a result of core modification was evaluated and is reported in APAE Memo No. $194^{4}$.

\subsection{Reactivity of Smaller Cores}

Experiments were performed to determine the loss of reactivity associated with the removal of fuel elements from rore positions $12,21,16,27,67,76,61$, and 72 . In the first ex periment, only the fiuel elements in positions $16,27,61$, and 72 were removed and the reactivity effect measured. It was as sumed that the measured effect could be mulitplied by two to obtain an estimate of the effect of removing 8 futel elements. Because the measured reactivity loss was large and adversely af fected the estimate of the PM-2A lifetime, it was decided to perform a second experiment in which 8 elements were removed from the $S M-1$ core.

The general procedure for both experiments was to calibrate rod $A$ as a function of the five rod bank position in the normal SM-1 core; and then in the ore with elements removed : The in tegral worth of rod A was used to calibrate the five rod ban (see section 2.2) Five rod bank ealibrations are shown in Fig. 
2.5.1. The reactivity change associated with fuel element changes is subject to different interpretations because of the change in rod worth with core size and bank position.

Table 2.5-1 gives the results of $\Delta p$ computed on the basis of rod calibrations in the various cores, . To estimate the reactivity remaining in the 45 and 37 element cores, the differential bank worth curves were extrapolated linearly to zero at 22 inches, as shown in Figure 2.5.2. The differential curves in Figure 2.5.2 were integrated to yield Figure 2.5.3, The straight line extrapolation of Fig. 2.5.2 yields an integral worth from 7.09 inches to 22 inches, which agrees within $0.1 \%$. With the integral worth taken from the differential worth curve in APAE Memo $178^{1}$.

. The critical five rod bank positions in the 45 and 37 element cores were 7.09 inches and 9.54 inches, respectively. Reading from Figure 2.5,3 at these positions,

$$
\begin{aligned}
& 22.0
\end{aligned}
$$

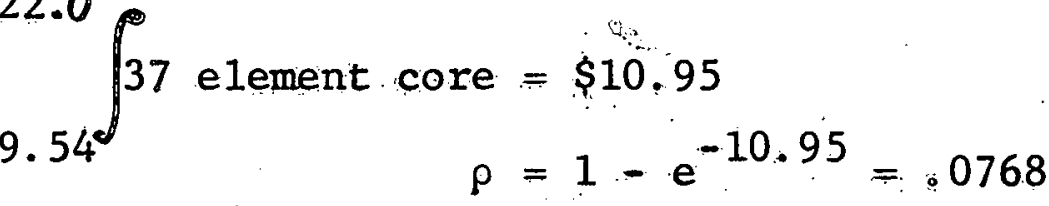

$$
\begin{aligned}
& \int_{7.09}^{22.0} 45 \\
& 45 \text { element core }=\$ 13,90 \\
& \rho=1-\mathrm{e}^{-13.90}=0.0964 \\
& \Delta \rho=\int_{7.09}^{22.0} 45 \text { element core }-\quad \int_{9.54}^{22.0 p} 37 \text { element core }=1.96 \%
\end{aligned}
$$

The integral bank worth method of determining the reactivity difference between the two cores has the advantage of correctly treating the change in bank worth with core size. However, it is subject to a large uncertainty due to the extrapolation employed. This method yields a value of $\Delta p 45 \rightarrow 37=-14.6 \%$. 
FIGLRE 2.5.1

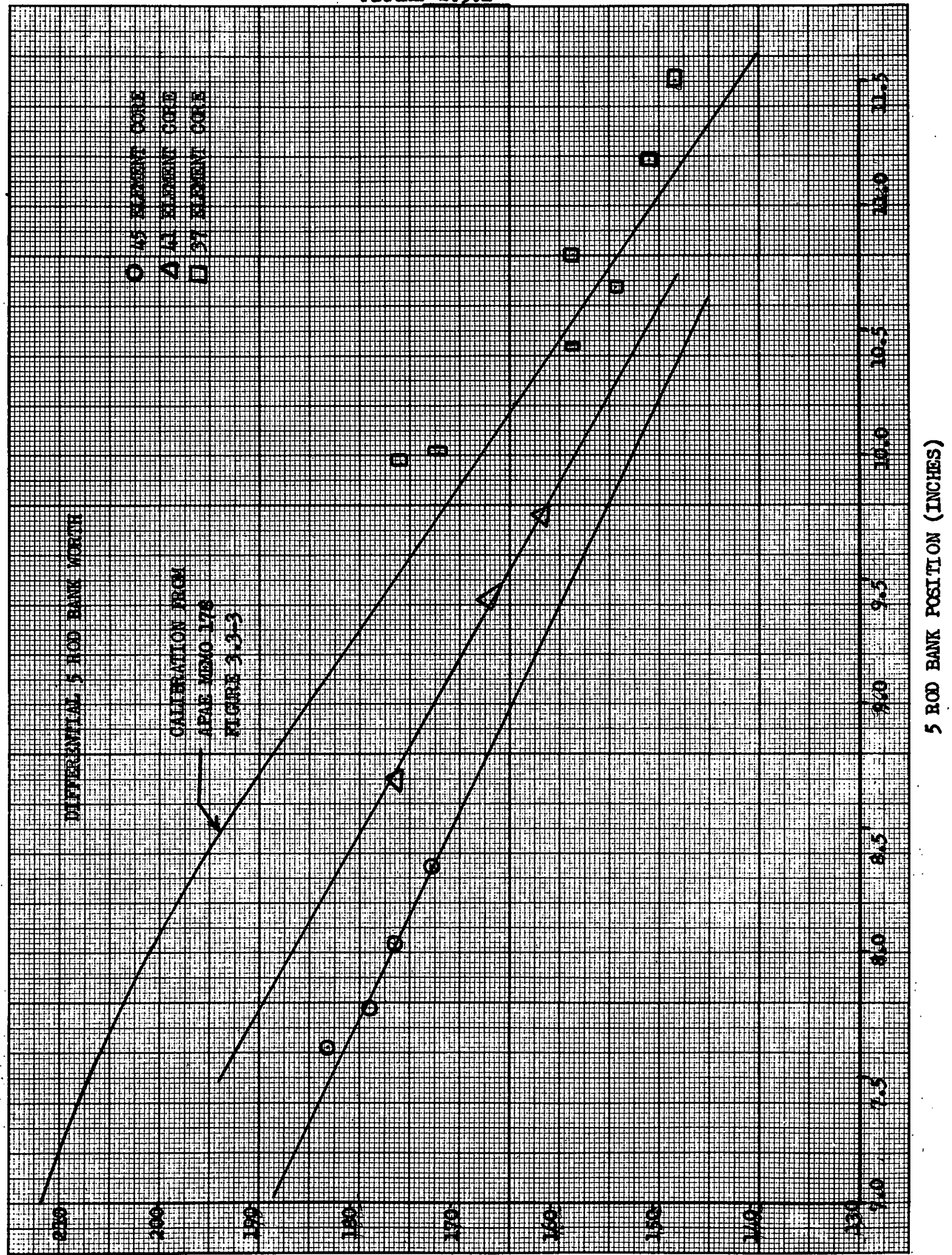

(UT/ $\neq$ ) HLZDM SNVG GOY $S$ 


\section{TABLE 2. $5-1$}

Reactivity Change Associated with Fue1

Element Changes

$\begin{array}{lcc}\begin{array}{l}\text { Change in } \\ \text { Number of } \\ \text { Elements }\end{array} & \begin{array}{l}\text { Reactivity Loss } \\ \text { (based on larger core } \\ \text { Bank calibration) }\end{array} & \begin{array}{c}\text { Reactivity Gain } \\ \text { (based on smaller core } \\ \text { bank calibration) }\end{array} \\ \begin{array}{l}1.43 \% \\ 45 \text { to } 41\end{array} & 3.09 \% & \\ 45 \text { to } 37 & & 1.51 \% \\ 41 \text { to } 45 & & 3.51 \%\end{array}$


FIGRB 2.5.2




FIGURE 2.5 .3

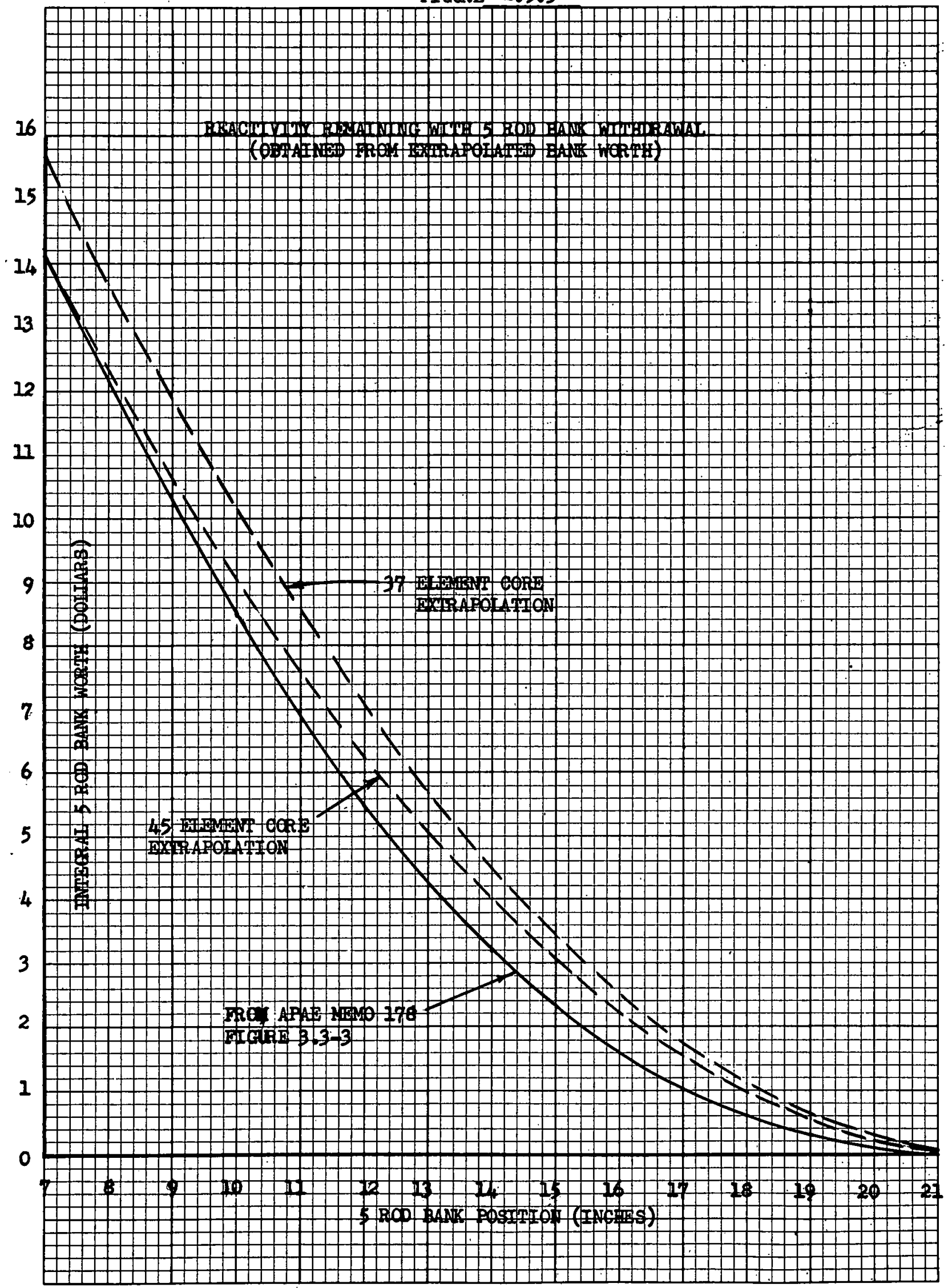




\subsection{Neutron Flux Measurements}

The relative neutron flux in the core, in the region of an integral europium flux suppressor in a fuel element, and in the shield rings, was measured by the activation of gold foils.

\subsubsection{Shielding}

For the measurement of the relative neutron flux attenuation between the core and the shield rings, foils were placed in fuel element positions 35 and 62 in the core and in the water gaps between shield rings $1,2,3,4$; and 5 . The foils were activated for 10 hours with the reactor operating at a power level of $10 \mathrm{kw}$. The reactor was then shutdown and the foils rew moved. The activity of the foils was determined and decay corrected to the time of shutdown. Corrections were made using the relative axial flux plot 1 for the displacement of the foils in the core from the relative peak flux. The activity of cadmium covered gold foils activated in the core was normalized to the calculated ${ }^{3}$ peak fast neutron flux in the core. The bare gold activity minus the cadmium covered gold foil activity for foils activated in the core was normalized to the calculated ${ }^{3}$ peak thermal neutron flux in the core. The normalization factors determined in the core for the fast and thermal fluxes were applied to the measurements between the shield rings. The com parison between the core-normalized relative gold foil activities and the calculated fast and thermal neutron fluxes in shield rings is shown in Figure 2,6.1. The figure shows the design shield ring spacing; however, the actual spacing may vary \pm 0.5 inches from the design. The variation in spacing from the design is the reason for the apparent inconsistant peaking of the thermal flux in water gaps. 


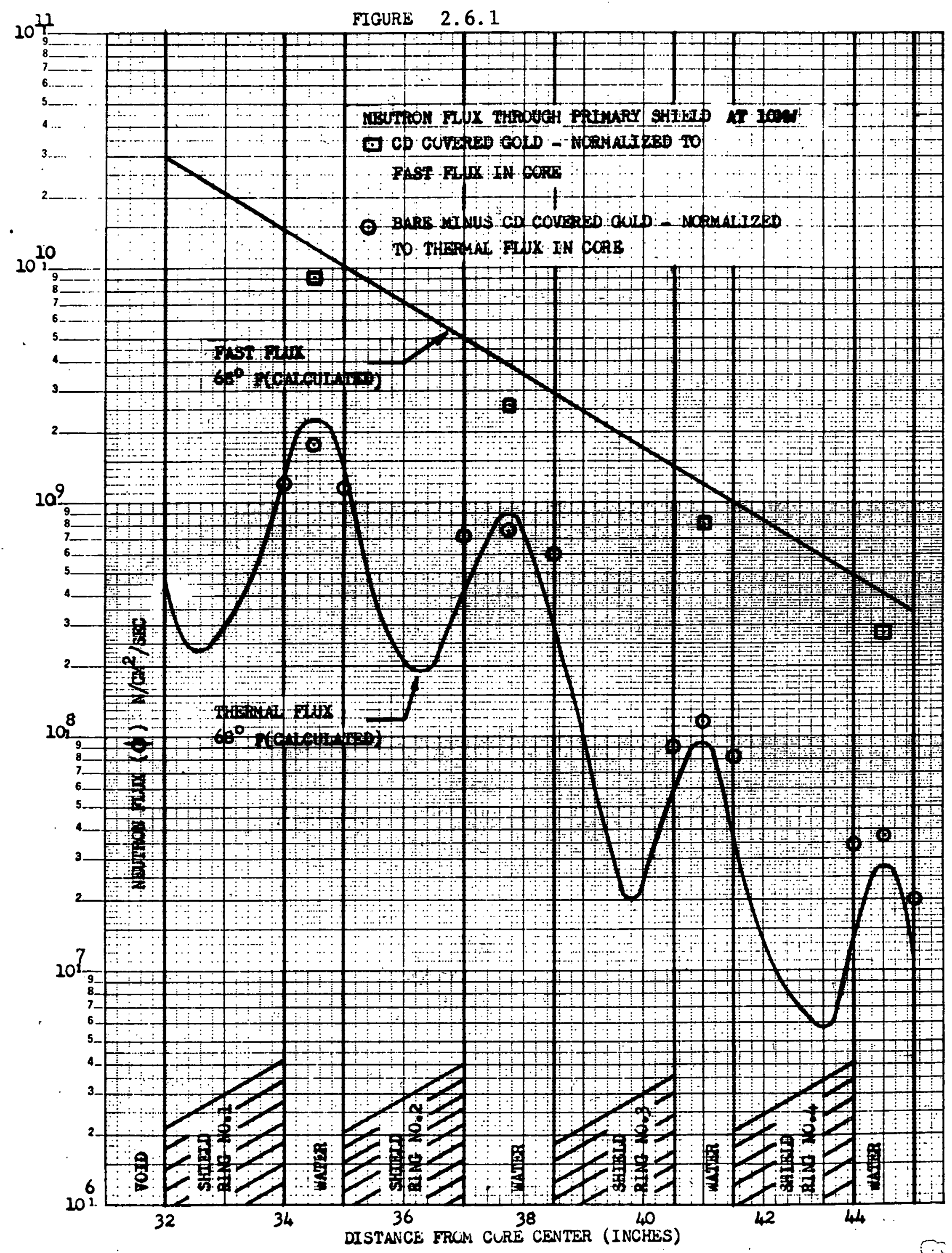




\subsubsection{Europium Flux Suppressors}

A new control rod fuel element containing integral europium flux suppressors was placed in control rod four. Gold foils were activated in the suppressor region to measure the effectiveness of the suppressor in reducing the thermal flux in the tip of the fuel element section of the control rod. Bare and cadmium covered gold foils were activated for 10 minutes with the reactor operating at a power level of approximately 80 watts. The reactor was shut down and the foils removed. The relative activity was determined and corrected to the time of shut-down. The activity of the bare gold foils minus the activity of the cad mium covered gold foils was normalized to a measurement of relative thermal flux with no suppressor ${ }^{4}$ between 2 and 3 inches bew low the top of the active fuel. Figure 2.6.2 shows a comparison of the relative thermal flux measured by gold foil activation for an integral europium suppressor; no suppressor; Haynes suppressor ${ }^{4}$; and the calculated thermal fiux for an integral europium suppres sor.

\section{7 Gamma Dose Rate Measurements}

\subsubsection{Above-Core}

The shut-down gamma flux was measured on March 31 , 1959 at points above the core. The air-walled ionization chamber used ta make the measurements is described in APAE No. $35^{3}$. To take measurements under water, the chamber was enclosed in a section of 3-inch diameter iron pipe, approximately 10 inches long. The pipe was gasketed and capped with aluminum on the lower end and attached by a welded connection on the top to a 1-inch diameter iron pipe 17 feet long. The upper pipe provided waterproof prois. tection for the electrical connections to the chamber and was marked to determine the position of the chamber: Measurements were taken at several positions above the core, and the dose rate 


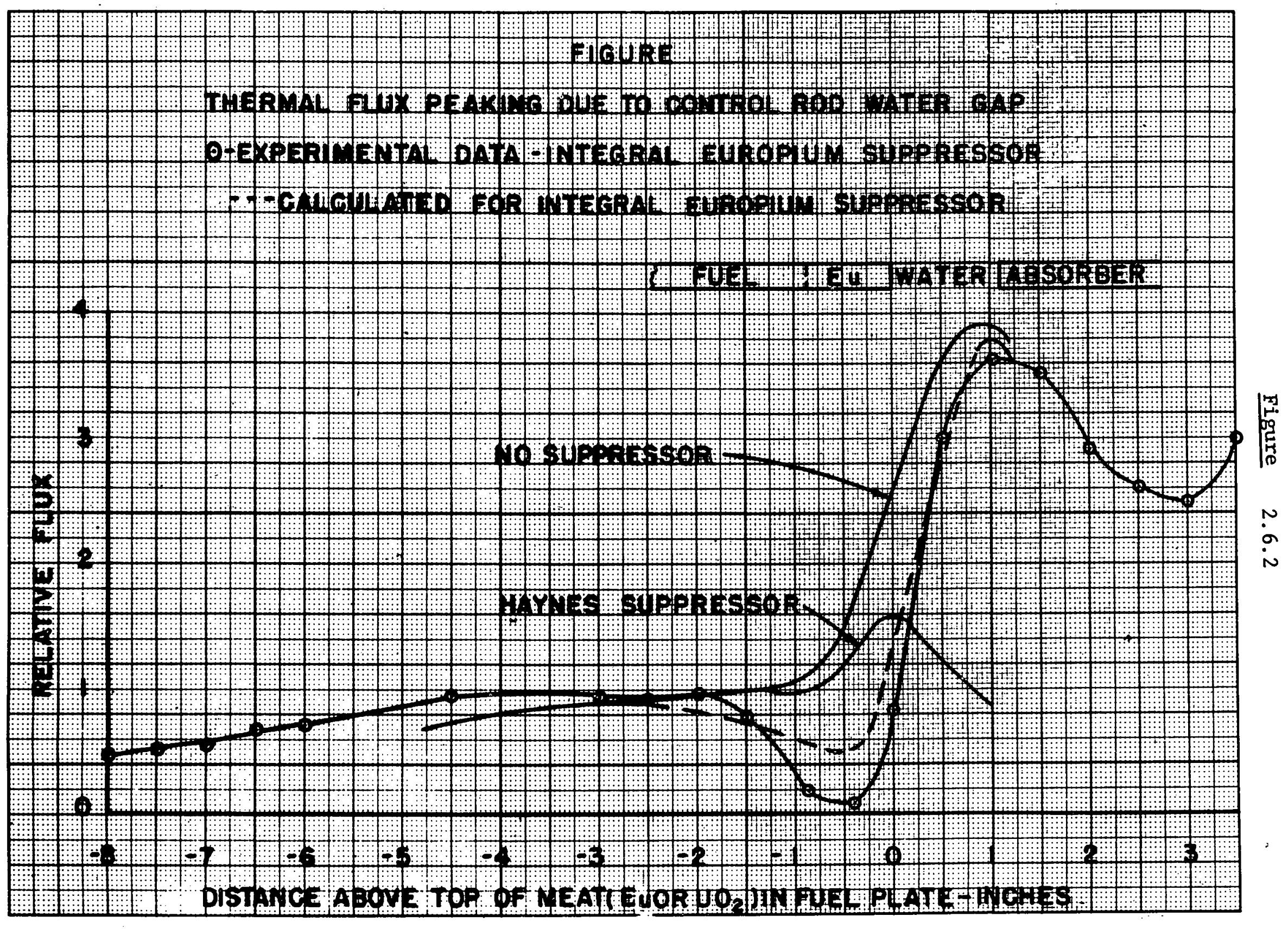


was calculated by the equation:

$$
D=E A I \frac{P_{0}}{P} \frac{T}{T_{O}}
$$

where

$$
\begin{aligned}
& \mathrm{D}=\text { dose rate } \quad \mathrm{R} / \mathrm{hr} \\
& \mathrm{F}=\text { chamber sensitivity }=\mathrm{R} / \mathrm{hr} \log \text { Af } \mathrm{A} \text { at } \mathrm{S}_{\mathrm{Q}} \mathrm{T}_{0} \mathrm{P}_{0}=0.2452 \\
& A=\text { attenuation through pipe wall }=2.72 \\
& P_{0}=\text { s.tandard pressure }-.760 \mathrm{~mm} \text { of } \mathrm{Hg} \\
& P=\text { pressure in chamber during measurement } \\
& \text { (assumed to be } 760 \mathrm{~mm} \text { of } \mathrm{Hg} \text { ) } \\
& \mathrm{T}_{\mathrm{O}}=\text { standard temperature } \doteqdot 492^{\circ} \mathrm{R} \\
& T=\text { temperature in chamber during measurement }\left(530^{\circ} \mathrm{R}\right) \\
& I=\text { chamber current (opy amperes) }
\end{aligned}
$$

The shut-down gamma dose rate plotted as a function of position above the core centerline is shown in Fig. 2.7.1. The results. shown in Fig. 2.7.1 are difficult to interpret with respect to generated fission products because of intermittent reactor operation. The reactor was on line 183 hours in February and 69 hours in March.

\subsubsection{Contro1 Rod Components}

The ganma dose rate from components of safety rod A was measured with a Jordon probe. Measurements were made with the instrument approximately one inch from the surface of the water and one inch from the holding tool, with the component underwater, or one inch from the component when removed from the water.

1)... Fue 1. Element Section

The gamma dose rate with the fuel element section underwater is plotted in Figure 2.7.2. The distance is measured from the surface of the water to the bottom of the element pin. The dose rate is greater than $50 \mathrm{R} / \mathrm{hr}$. with the fuel element section less than 2.3 feet underwater. 


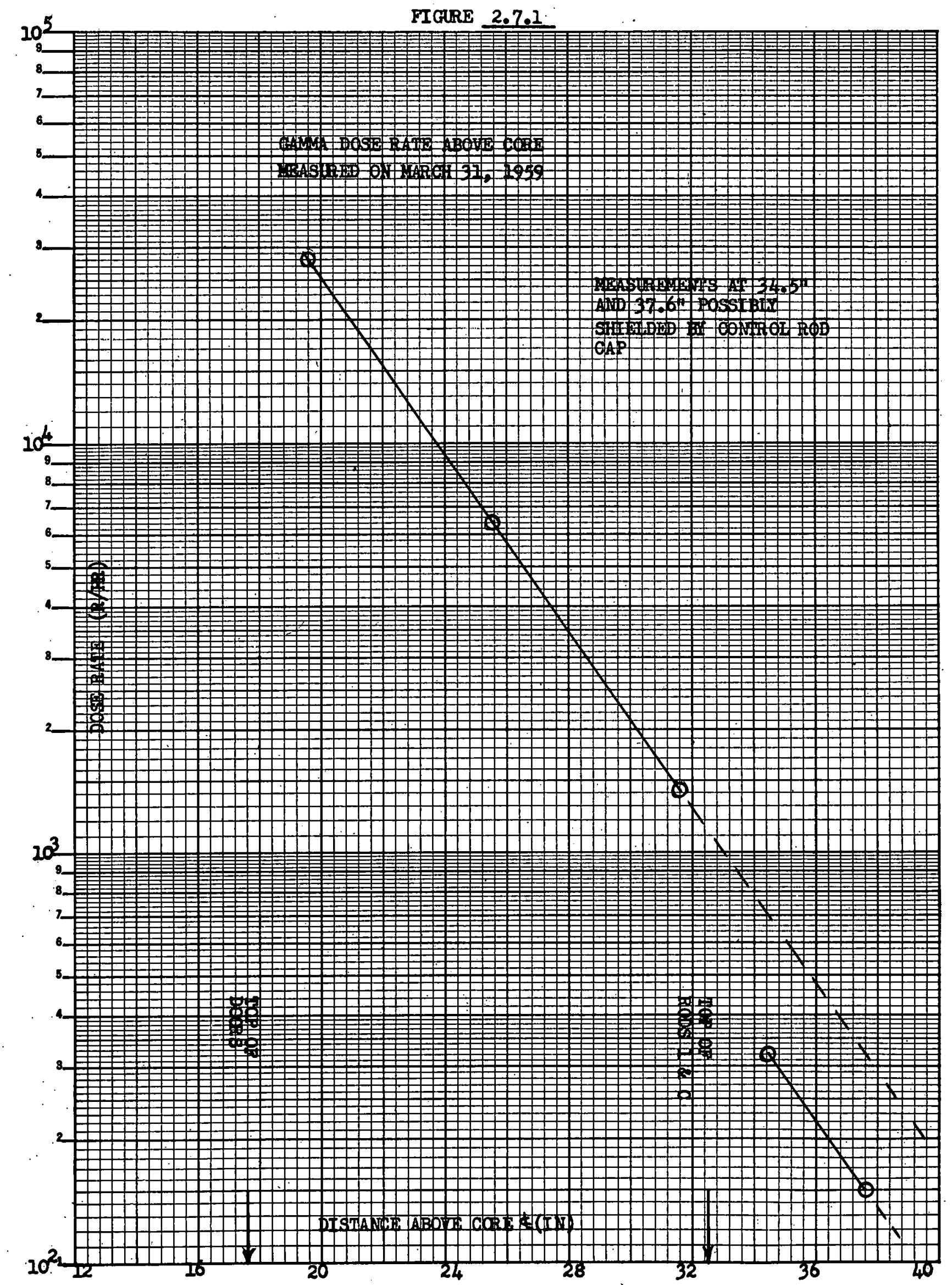




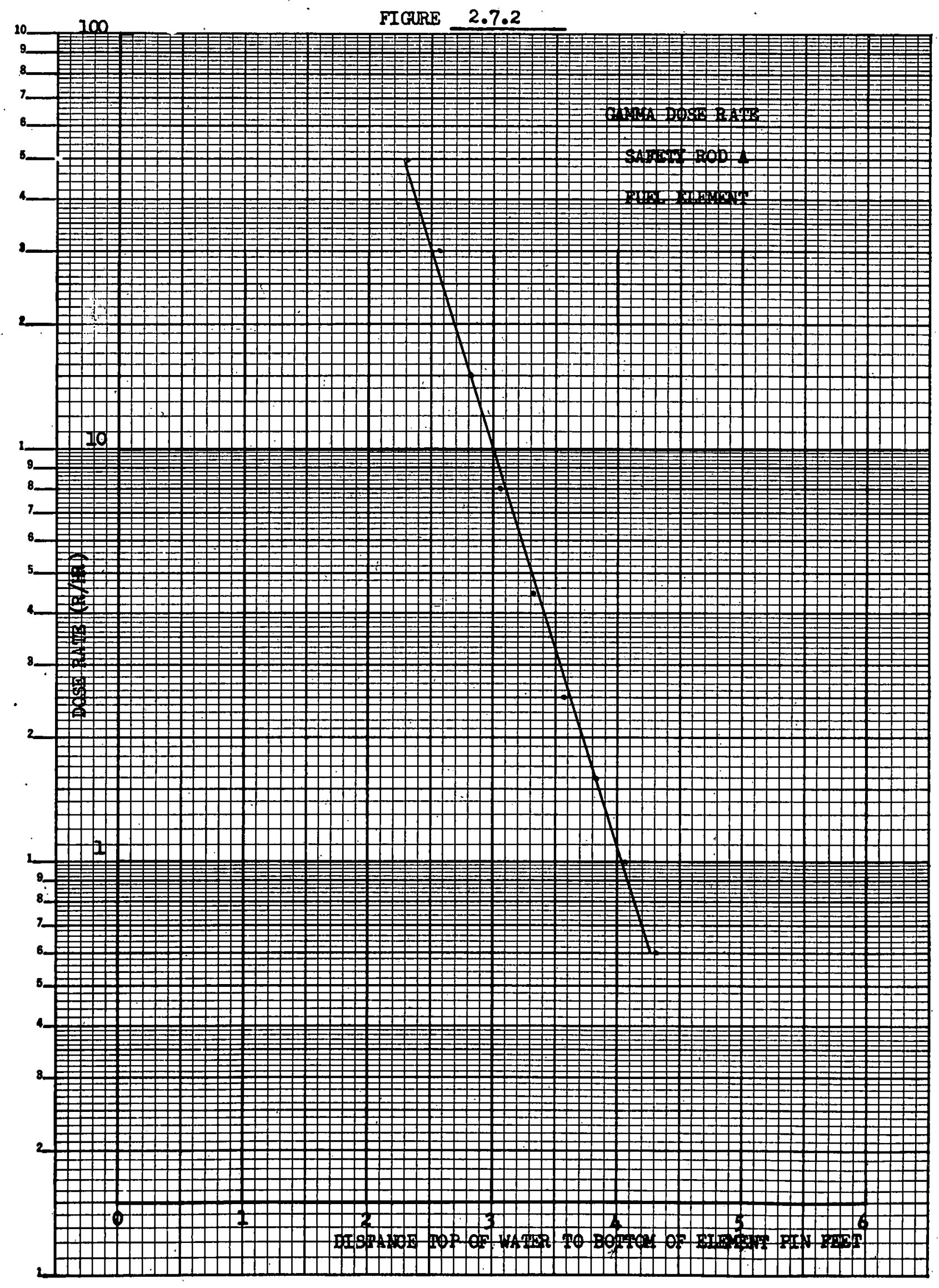


2) Boron Absorber Section

The gamma dose rate was measured with the boron absorber section underwater and also with it fully exposed. The results of the measurements are tabulated in Table 2.7-1. The measurements with the absorber fully exposed give a dose rate greater than $50 \mathrm{R} / \mathrm{hr}$ when the detector is placed more than 9.5 inches below the top.

3) Rod Cap

The gamma dose rate was measured with the rod cap under water and when fully exposed, The results are tabulated in Table 2.7-2. Measurements with the cap fully exposed gave a maximum dose rate of $2.7 \mathrm{R} / \mathrm{hr}$. However, it should be noted that rod $A$ is withdrawn during operation at power, and the top of the cap is then approximately 51 inches above the center of the core. 
TABLE, $2.7-1$

Gamma Dose Rate from Safety Rod A Boron

Absorber Element

\begin{tabular}{|c|c|}
\hline Measurement Position & $\begin{array}{l}\text { Dose } \\
\text { Rate } \\
\text { R/hr }\end{array}$ \\
\hline 6.5 inches from top of water to bottom of element pin & 0.06 \\
3.5 inches from top of water to bottom of element pin & 0.6 \\
0.5 inches from top of water to bottom of element pin & 1.3 \\
( 125 inches of element exposed) & 15 \\
9.0 inches from top of element completely exposed & 50 \\
\hline
\end{tabular}

All of element more than 9.5 inches from top of element completely exposed

greater than 50 
TABLE $2,7-2$

GAMMA DOSE RATE FROM SAFETY ROD A CAP

Measurements Are From the Surface of the Water to the End of the Tool Installed on the Cap.

MEASUREMENT POSITION

Dose

Rate

$(\mathrm{R} / \mathrm{hr})$

- 10 feet under water

0.5

40 feet above water

1.4

.65 feet above water

1,5

$.89^{\circ}$ feet above water

2.4

1. 15 feet above water

2. 7

Cap clear of water, measured 0.5 inches from spring

2.4 


\section{0 CONCLUSIONS}

The experimental measurements included in this report indicate that:

1. The unsatisfactory performance of $B F_{3}$ neutron counters for short times after shut-down is ap parently caused by high gamma flux.

2. Modifications made to the core will not seriously hinder the interpretation of measurements made under Task. VII

3. Measurements of the neutron flux verify the calculated ${ }^{4}$ attenuation of neutrons to the biological shield and show that an integral europium suppressor effectively reduces the thermal flux peak at the tip of a control rod fuel element.

4. The total energy release will be approximately 15 MWYR. 
1) MacKay, S.D., et. a1;, "SM-1 (APPR-1) Research and Development Program Interim Report on Core Measurements - Task No VII", APAE Memo No. 178, Issued March 1, 1959

2) Byrne, B.o.s, et. a1;,"Nuclear Effects due to Replacement of Fuel Elements in SM-1", AP Note No. 143, Issued April 1959

3) Rosen, S.S., et. a1. "APPR-1 Research and Development Program, Shielding Experiments and Analyses - Task No. VI", APAE No.. 35, Issued October 15; 1958

4) Fried, B.E., MacKay, S.D., "Evaluation of Hazards Associated with SM-1 Çore I Modification", APAE Memo No. 194, Issued May 8,1959

5) Williamson, T.G., et. al., "Reactor Analysis APPR-1 Core II", APAE No. . 32, Issued July 15, 1958 
$S M-2$

RESEARGH AND DEVELOPMENT PROGRAM

INTERIM REPORT NO, 2

ON

CORE MEASUREMENTS

TASK No. VII

Alco Products, Inc. Post Office Box 414 Schenectady, $N_{\circ} \cdot Y$. 